\title{
Short-term Temperature Change Affects the Carbon Exchange Characteristics and Growth of Four Bedding Plant Species
}

\author{
Marc W. van Iersel \\ Department of Horticulture, The University of Georgia, Miller Plant Science Building, Athens, GA 30602-7273
}

\begin{abstract}
AdDitional INDEX wORDs. carbon use efficiency, maintenance respiration, photosynthesis, $\mathrm{Q}_{10}$, relative growth rate, respiration, Pelargonium $\times$ hortorum, Petunia $\times$ hybrida, Tagetes patula, Viola $\times$ wittrockiana

Abstract. Bedding plants are exposed to a wide range of environmental conditions, both during production and in the landscape. This research compared the effect of short-term temperature changes on the $\mathrm{CO}_{2}$ exchange rates of four popular bedding plants species. Net photosynthesis $\left(\mathbf{P}_{\text {net }}\right)$ and dark respiration $\left(\mathbf{R}_{\text {dark }}\right)$ of geranium (Pelargonium $\times$ hortorum L.H. Bail.), marigold (Tagetes patula L.), pansy (Viola $\times$ wittrockiana Gams.), and petunia (Petunia $\times$ hybrida Hort. Vilm.-Andr.) were measured at temperatures ranging from 8 to $38{ }^{\circ} \mathrm{C}$ (for $P_{\text {net }}$ ) and 6 to $36{ }^{\circ} \mathrm{C}$ (for $\mathbf{R}_{\text {dark }}$ ). Net photosynthesis of all species was maximal at 14 to $15{ }^{\circ} \mathrm{C}$, while $R_{\text {dark }}$ of all four species increased exponentially with increasing temperature. Gross photosynthesis $\left(P_{\text {gross }}\right)$ was estimated as the sum of $\mathbf{P}_{\text {net }}$ and $\mathbf{R}_{\text {dark }}$, and was greater for petunia than for the other three species. Gross photosynthesis was less sensitive to temperature than either $\mathbf{P}_{\text {net }}$ or $\mathbf{R}_{\text {dark }}$, suggesting that temperature effects on $P_{\text {net }}$ were caused mainly by increased respiration at higher temperatures. Gas exchange-temperature response curves were not useful in determining the heat tolerance of these species. There were significant differences among species in the estimated $R_{\text {dark }}$ at $0{ }^{\circ} \mathbf{C}$ and the $Q_{10}$ for $R_{\text {dark }}$. Differences in the $Q_{10}$ for $R_{\text {dark }}$ were related to growth rate and plant size. Large plants had a greater $Q_{10}$ for $R_{\text {dark, }}$, apparently because these plants had a higher ratio of maintenance to growth respiration than small plants. The $Q_{10}$ of the maintenance respiration coefficient was estimated from the correlation between the $Q_{10}$ and relative growth rate, and was found to be 2.5 to 2.6.
\end{abstract}

Temperature affects growth and physiology of plants, both during production and in the landscape. A thorough understanding of temperature effects on plant growth is needed to develop guidelines for optimal temperatures during production, and can help to predict plant performance during production and in landscapes. Since almost all dry weight accumulation of plants is the result of carbon fixation, $\mathrm{CO}_{2}$ exchange rate measurements are particularly useful in predicting plant growth. Photosynthesis and respiration temperature-response curves of various species have been used to predict plant performance and heat tolerance (Higgins et al., 1992; Leonardos et al., 1994; Ranney and Peet, 1994; Ranney and Ruter, 1997).

Most commonly, $\mathrm{CO}_{2}$ exchange rates of individual leaves have been measured (Higgins et al., 1992; Larigauderie and Körner, 1995; Martindale and Leegood, 1997; Ranney and Peet, 1994; Ranney and Ruter, 1997). Leaf photosynthesis measurements can provide valuable physiological information (e.g., stomatal conductance, $\mathrm{CO}_{2}$ concentrations in the stomatal cavity) and allow for relatively easy measurements of the environmental effects (e.g., light intensity, temperature, $\mathrm{CO}_{2}$ concentration) on gas exchange rates. However, leaf gas exchange measurements often are poorly correlated with growth or yield (Elmore, 1980; Evans, 1993). Leaf measurements ignore differences in total leaf area, spatial variability within a canopy, and respiratory $\mathrm{CO}_{2}$ efflux from roots, stems, flowers, and fruits (van Iersel and Bugbee, 2000). Therefore, whole plant measurements can give a better indication of environmental effects on plant growth.

Zelitch (1982) has shown that there generally is a good correlation between canopy photosynthesis and dry matter production or yield. However, reports of whole-plant $\mathrm{CO}_{2}$ exchange rate measurements to determine how floricultural crops respond

Received for publication 17 May 2002. Accepted for publication 17 Oct. 2002. I thank Jonathan Frantz for his helpful discussions of the data, Keven Calhoun and Larry Freeman for their technical assistance, and the Fred C. Gloeckner Foundation for their financial support of this research. to changing environmental conditions appear rare. Leonardos et al. (1994) measured whole-plant $\mathrm{CO}_{2}$ exchange rates of Alstroemeria at different light intensities, atmospheric $\mathrm{CO}_{2}$ concentrations, and temperatures, and Miller et al. (2001) measured the effects of light intensity and temperature on $\mathrm{CO}_{2}$ exchange rates of two angelonia (Angelonia angustifolia Benth.) cultivars.

The objectives of this study were to determine whether species from different genera respond differently to short-term temperature changes, and whether whole-plant $\mathrm{CO}_{2}$ exchange responses to temperature can be used as an indicator of the heat tolerance of bedding plants. Photosynthesis-temperature response curves commonly are used to compare the heat tolerance of species, but these data normally are collected at the single leaf level (e.g., AlKhatib and Paulsen, 1999; Higgins et al, 1992; Ranney and Ruter, 1997). No studies which compare the responses of whole plant $\mathrm{CO}_{2}$ exchange rates of different species to temperature could be identified. The four species used in this study were geranium (Pelargonium $\times$ hortorum), petunia (Petunia $\times$ hybrida), marigold (Tagetes patula), and pansy (Viola $\times$ wittrockiana). These species were selected because they are among the most popular bedding plant species in the United States and differ in heat tolerance. Pansy performs well at cool temperatures, but is particularly heatsensitive and generally does not survive summers in a warm climate like that in the southeastern United States. The other three species are better adapted to high temperatures and generally perform well at higher temperatures than pansy (Armitage, 1994). Initial analysis of the data revealed differences in the response of dark respiration $\left(\mathrm{R}_{\text {dark }}\right)$ to temperature among species. Therefore, another objective of this study was to explain these differences.

\section{Materials and Methods}

Plant material. Marigold 'Antigua orange', geranium 'Pinto violet', petunia 'Dreams red', and pansy 'Scarlet bronze' seedlings were received from a commercial grower (Speedling, Inc., Blairsville, Ga.) on 17 Sept. 1999 and transplanted into 10-cm 
(510-mL) square pots filled with a peat-based growing medium (MetroMix 300; Scotts Co., Marysville, Ohio). The plants were placed in a double-layer polyethylene-covered greenhouse and watered as needed. Plants were fertilized twice weekly with a water-soluble fertilizer solution containing $200 \mathrm{mg} \cdot \mathrm{L}^{-1} \mathrm{~N}$, made with a $20 \mathrm{~N}-4.3 \mathrm{P}-16.6 \mathrm{~K}$ fertilizer (20-10-20 Peat-lite Special, Scotts Co.). Greenhouse temperature and relative humidity averaged $25^{\circ} \mathrm{C}$ and $60 \%$, respectively.

Measurements. $\mathrm{CO}_{2}$ exchange measurements were started on 18 October. Data were collected with a semicontinuous, 10-chamber, whole-plant gas exchange system (van Iersel and Bugbee, 2000). Multiple plants (15 in this case) can be measured together inside one gas exchange chamber simultaneously, thus reducing experimental error caused by plant-to-plant variability. The gas exchange system consisted of acrylic chambers $(0.32 \times 0.5 \times 0.6$ $\mathrm{m}^{3}$ ), eight of which were placed in two growth chambers (model E15; Conviron, Winnipeg, Canada), and the other two chambers were placed outside of the growth chambers and were measured without any plants in them. Gas exchange of eight groups of 15 plants (two groups from each species) was measured simultaneously. Air flow through each gas exchange chamber $\left(\approx 0.5 \mathrm{~L} \cdot \mathrm{s}^{-1}\right)$ was measured with mass flow meters (GFM37-32; Aalborg Instruments and Controls, Monsey, N.Y.) and the difference in $\mathrm{CO}_{2}$ concentration between the air entering and exiting the gas exchange chambers was measured with an infrared gas analyzer (IRGA) in differential mode (LI-6262; LI-COR, Lincoln, Nebr.). Whole-chamber $\mathrm{CO}_{2}$ exchange rates $\left(\mu \mathrm{mol} \cdot \mathrm{s}^{-1}\right)$ were calculated as the product of mass flow $\left(\mathrm{mol} \cdot \mathrm{s}^{-1}\right)$ and the difference between the $\mathrm{CO}_{2}$ concentration of the air entering and exiting the chamber $\left(\mu \mathrm{mol} \cdot \mathrm{mol}^{-1}\right)$. Each chamber was measured for $30 \mathrm{~s}$, once every $10 \mathrm{~min}$. Gas exchange data were corrected for zero drift of the IRGA, by subtracting the $\mathrm{CO}_{2}$ exchange rate of the empty chambers from that of the chambers with plants in them.

Fifteen plants from a single species were placed in a gas exchange chamber to determine carbon exchange rate-temperature response curves. Since there were eight gas exchange chambers available, two replications of the four species could be measured at one time. Since only two replications could be measured simultaneously, the experiment was repeated in time to obtain a total of four replications of each species. The first two replications were measured 32 and $33 \mathrm{~d}$ after transplanting and the last two replications at 39 and $40 \mathrm{~d}$ after transplanting.

Plants were placed inside the gas exchange chambers the evening before the start of the measurements and kept in the dark for $16 \mathrm{~h}$, while the growth chamber temperature was gradually decreased from 23 to $10{ }^{\circ} \mathrm{C}$. The growth chamber temperature then was decreased to $1{ }^{\circ} \mathrm{C}$ at the start of the photosynthesis measurements. Net photosynthesis-temperature response curves were determined during a 24-h period, during which the growth chamber temperature was increased stepwise from 1 to $36{ }^{\circ} \mathrm{C}$ in $5^{\circ} \mathrm{C}$ steps of $3 \mathrm{~h}$ each. Due to radiative heating by the lights, actual air temperatures inside the gas exchange chambers were higher than in the rest of the growth chamber and ranged from 8 to $38^{\circ} \mathrm{C}$. Each temperature was maintained for $3 \mathrm{~h}$, but only data from the last hour were used for analysis. This allowed the gas exchange measurements to stabilize after the temperature was changed. Since whole plants, and the pots in which they were grown, were placed in the gas exchange chambers, the measurements represent the combined effects of shoots, roots, and microbial respiration in the growing medium. Microbial respiration is negligible compared to plant $\mathrm{CO}_{2}$ exchange, unless small plants are grown in relatively large pots. Thus, microbial respiration likely had little effect on the measured $\mathrm{CO}_{2}$ exchange rates.
Air temperatures inside the gas exchange chambers were measured with shielded, aspirated, type T thermocouples. Light was provided by fluorescent lamps and photosynthetic photon flux density at the top of the plant canopies was $650 \mu \mathrm{mol} \cdot \mathrm{m}^{-2} \cdot \mathrm{s}^{-1}$. Relative humidity inside the gas exchange chambers was not controlled and ranged from $\approx 85 \%$ at $8{ }^{\circ} \mathrm{C}$ to $70 \%$ at $38{ }^{\circ} \mathrm{C}$ as measured with capacitance sensors (HTO-45, Rotronic, Huntington, N.Y.). Therefore, the vapor pressure deficit increased from 0.16 to $2.0 \mathrm{kPa}$ with increasing temperature. Since an increase in vapor pressure deficit with increasing temperature would be expected to occur under natural conditions as well, no attempt was made to control it. The $\mathrm{CO}_{2}$ concentrations inside the gas exchange chambers ranged from 300 to $400 \mu \mathrm{mol} \cdot \mathrm{mol}^{-1}$, depending on the photosynthetic $\mathrm{CO}_{2}$ uptake by the plants.

Dark respiration measurements were collected during the following 24-h period, during which the growth chamber temperature was decreased stepwise from 38 to $3{ }^{\circ} \mathrm{C}$, again in $5{ }^{\circ} \mathrm{C}$ steps of $3 \mathrm{~h}$ each. This resulted in temperatures ranging from 36 to $6{ }^{\circ} \mathrm{C}$ inside the gas exchange chambers. Relative humidity ranged from $100 \%$ at $6^{\circ} \mathrm{C}$ to $70 \%$ at $38{ }^{\circ} \mathrm{C}$ and the vapor pressure deficit increased from 0 to $2.0 \mathrm{kPa}$. $\mathrm{CO}_{2}$ concentrations ranged from 410 to $470 \mu \mathrm{mol} \cdot \mathrm{mol}$, depending on the respiratory $\mathrm{CO}_{2}$ efflux from the plants. Shoot and root dry weights (DW) of the plants were determined after finishing the respiration measurements.

Data ANALYSIS. Net photosynthesis-temperature response curves were fitted using quadratic models $\left(R^{2}>0.98\right)$. Results of the regression analysis were then used to estimate the temperature at which $\mathrm{P}_{\text {net }}$ reached a maximum.

Temperature response coefficients $\left(Q_{10}\right)$ for dark respiration were determined by fitting an exponential curve to the data $\left(R^{2}>\right.$ $0.97)$

$\mathrm{R}_{\text {dark }}=\mathrm{R}_{\mathrm{o}} \times \mathrm{Q}_{10}{ }^{(\mathrm{T} / 10)}$

where $\mathrm{R}_{0}$ is the estimated $\mathrm{R}_{\text {dark }}$ at $0{ }^{\circ} \mathrm{C}\left(\mu \mathrm{mol} \cdot \mathrm{s}^{-1}\right), \mathrm{Q}_{10}$ is the relative increase in $\mathrm{R}_{\mathrm{dark}}$ with a $10{ }^{\circ} \mathrm{C}$ increase in temperature, and $\mathrm{T}$ is the temperature $\left({ }^{\circ} \mathrm{C}\right)$.

A temperature response curve for gross photosynthesis $\left(\mathrm{P}_{\text {gross }}\right)$ was constructed by adding the estimated rates of $P_{\text {net }}$ and $R_{\text {dark }}$ at a specific temperature, assuming that respiration rates were the same in the light as in the dark. $\mathrm{Q}_{10}$ values for $\mathrm{P}_{\text {net }}$ and $\mathrm{P}_{\text {gross }}$ at temperature $\mathrm{T}$ were determined as the estimated photosynthetic rate at $\mathrm{T}+5^{\circ} \mathrm{C}$ divided by the rate at $\mathrm{T}-5^{\circ} \mathrm{C}$.

To predict the effect of temperature on plant growth rate, daily carbon gain of the plants $\left(\mathrm{DCG}, \mu \mathrm{mol} \cdot \mathrm{d}^{-1}\right)$ was estimated at different temperatures ( $\mathrm{T}$ ) using the regression results for $\mathrm{P}_{\text {net }}$ and $\mathrm{R}_{\text {dark }}$, assuming a 12-h light and 12-h dark period, and the same temperature in the light and dark:

$\mathrm{DCG}_{\mathrm{T}}=12 \times\left(\mathrm{P}_{\mathrm{net}, \mathrm{T}}-\mathrm{R}_{\text {dark }, \mathrm{T}}\right) \times 3600$

A photoperiod of $12 \mathrm{~h}$ was used for these calculations, because it is close to the natural photoperiod that the plants were exposed to in the greenhouse.

Carbon use efficiency at different temperatures $\left(\mathrm{CUE}_{\mathrm{T}}\right.$, $\mathrm{mol} \cdot \mathrm{mol}^{-1}$, the ratio of photosynthates incorporated into dry matter to carbohydrates fixed in photosynthesis) at different temperatures was estimated as (again assuming a $12 \mathrm{~h}$ photoperiod):

$\mathrm{CUE}_{\mathrm{T}}=\mathrm{DCG}_{\mathrm{T}} /\left(\mathrm{P}_{\text {gross }, \mathrm{T}} \times 12 \times 3600\right)$

For a more detailed evaluation of $\mathrm{CO}_{2}$ exchange differences among the species, the respiration rate at $25^{\circ} \mathrm{C}\left(\mathrm{R}_{25}\right)$ was esti- 


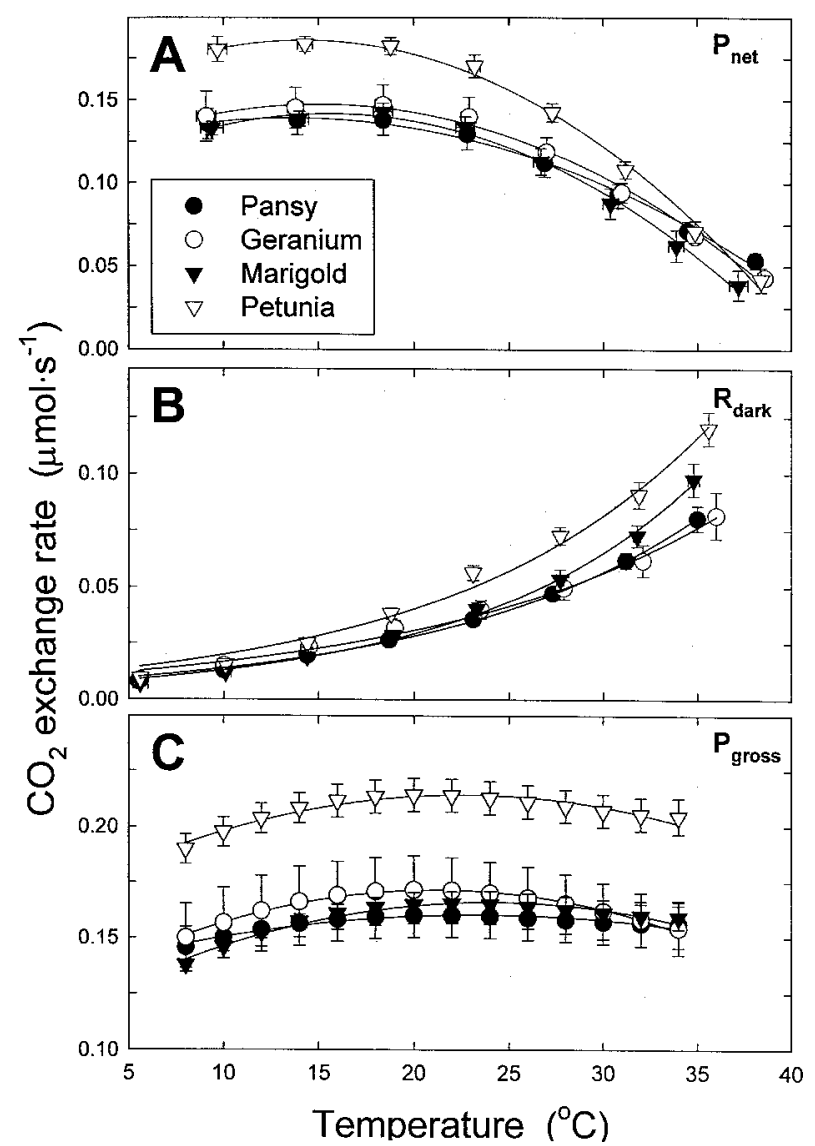

Fig. 1. Air temperature effects on the $\mathrm{CO}_{2}$ exchange rate of four bedding plant species. (A) Net photosynthesis $\left(\mathrm{P}_{\text {net }}\right)$ was measured at eight different temperatures during a $24 \mathrm{~h}$ period ( $3 \mathrm{~h}$ per temperature, increasing from 8 to $38^{\circ} \mathrm{C}$ ). (B) Dark respiration $\left(\mathrm{R}_{\text {dark }}\right)$ was measured during the subsequent $24 \mathrm{~h}$, with temperatures decreasing from 36 to $6^{\circ} \mathrm{C}$. (C) Gross photosynthesis $\left(\mathrm{P}_{\text {gross }}\right)$ was estimated as the sum of the regression curves fitted to the $\mathrm{P}_{\text {net }}$ and $\mathrm{R}_{\text {dark }}$ data. Net photosynthesis data were fitted with a quadratic model $\left(R^{2}>0.98\right)$, and $\mathrm{R}_{\text {dark }}$ data with an exponential model $\left(R^{2}>0.97\right)$. Data points are the mean gas exchange rates per plant \pm 1 standard error $(n=4)$. Error bars not shown are within the limit of the symbol.

mated from the temperature response curves, and the specific respiration rate at $25^{\circ} \mathrm{C}\left(\mathrm{R}_{25} / \mathrm{DW}\right)$ was calculated as $\mathrm{R}_{25}$ divided by the dry weight of the plants. Respiratory effects were studied more closely at $25^{\circ} \mathrm{C}$, because this was the average greenhouse temperature at which the plants were grown. Relative growth rate at $25^{\circ} \mathrm{C}\left(\mathrm{RGR}_{25}, \mathrm{~mol} \cdot \mathrm{g}^{-1} \cdot \mathrm{d}^{-1}\right)$ was calculated as the ratio between DCG and total plant dry weight:

$\mathrm{RGR}_{25}=\mathrm{DCG}_{25} / \mathrm{DW}$

$\mathrm{All} \mathrm{CO}_{2}$ exchange rates are expressed on a per plant basis (i.e., measured whole-chamber $\mathrm{CO}_{2}$ exchange rates divided by 15 plants per chamber).

The experiment was designed as a randomized complete block with four treatments (species) and four replications. The experimental unit was a group of 15 plants within a gas exchange chamber, and four groups of 15 plants (one group of each species) inside a single growth chamber was a replication. Data were analyzed by regression and analysis of variance. Due to differences in plant size, there were significant differences between the first and last two replications for many of the measured and calculated parameters. This was accounted for in the statistical analysis by including the block (i.e., replication) effect in the analysis of variance. Means were separated with tukey's multiple comparison procedure.

\section{Results and Discussion}

Net photosynthesis of all four species increased as temperatures were increased above $8{ }^{\circ} \mathrm{C}$, reached a maximum between 13.4 and $15.5^{\circ} \mathrm{C}$, and decreased again at higher temperatures (Fig. 1, Table 1). This photosynthetic response to temperature is typical for many $\mathrm{C}_{3}$ species (Bednarz and van Iersel, 2001; Higgins et al., 1992; Leonardos et al., 1994; Miller et al., 2001; van Iersel and Lindstrom, 1999) and is consistent with the model for Rubisco-limited photosynthesis by Bernacchi et al. (2001). Although the optimal temperature for $\mathrm{P}_{\text {net }}$ may be species-dependent (Higgins et al., 1992), there were no significant differences in optimal temperature for $\mathrm{P}_{\text {net }}$ among the species used in this study (Table 1). Petunia had a higher $\mathrm{P}_{\text {net }}$ than the other three species at most temperatures $\left(<34^{\circ} \mathrm{C}\right)$, but its $\mathrm{P}_{\text {net }}$ declined more rapidly at supraoptimal temperatures, and all species had similar $\mathrm{P}_{\text {net }}$ at 34 to $38^{\circ} \mathrm{C}$. Higgins et al. (1992) also reported that $\mathrm{P}_{\text {net }}$ of different species respond differently to short-term temperature changes, while van Iersel and Lindstrom (1999) reported differences in photosynthesis responses to temperature among three magnolia (Magnolia grandiflora L.) cultivars.

Dark respiration increased exponentially for all species, with significant differences in $\mathrm{R}_{0}$ and $\mathrm{Q}_{10}$ among the species (Table 1). Geranium and petunia had the highest $\mathrm{R}_{0}$, while marigold and petunia had the highest $Q_{10}$ for $R_{\text {dark }}$. The combination of a high $R_{0}$ and $Q_{10}$ of petunia resulted in higher $R_{\text {dark }}$ of petunia than any of the other species at temperatures above $20{ }^{\circ} \mathrm{C}$. Since $\mathrm{R}_{0}$ is the whole-plant $\mathrm{R}_{\text {dark }}$ at $0{ }^{\circ} \mathrm{C}$, and thus depends on plant dry weight, specific respiration rates at $0{ }^{\circ} \mathrm{C}\left(\mathrm{R}_{0} / \mathrm{DW}\right)$ were calculated to correct for this. The specific respiration rate at $0^{\circ} \mathrm{C}$ was more than three times as high for geranium than for marigold, with intermediate values for pansy and petunia (Table 1 ).

Gross photosynthesis of petunia was $\approx 0.03 \mu \mathrm{mol} \cdot \mathrm{s}^{-1}$ higher than that of the other three species, independent of temperature $(P$

Table 1. Dry weight and calculated optimal temperature $\left(\mathrm{T}_{\text {opt }}\right)$ for net photosynthesis, $\mathrm{Q}_{10}$ for dark respiration, estimated whole plant dark respiration at 0 and $25^{\circ} \mathrm{C}\left(\mathrm{R}_{0}\right.$ and $\left.\mathrm{R}_{25}\right)$, specific dark respiration at 0 and $25^{\circ} \mathrm{C}\left(\mathrm{R}_{0} / \mathrm{DW}\right.$ and $\left.\mathrm{R}_{25} / \mathrm{DW}\right)$, daily carbon gain (DCG $\left.{ }_{25}\right)$, and relative growth rate $\left(\mathrm{RGR}_{25}\right)$ at $25^{\circ} \mathrm{C}$ of four bedding plant species.

\begin{tabular}{|c|c|c|c|c|c|c|c|c|c|}
\hline Species & $\begin{array}{l}\text { Dry wt } \\
\text { (g/plant) }\end{array}$ & $\begin{array}{c}\mathrm{T}_{\text {opt }}\left(\mathrm{P}_{\text {net }}\right) \\
\left({ }^{\circ} \mathrm{C}\right)\end{array}$ & $\begin{array}{l}\mathrm{Q}_{10}\left(\mathrm{R}_{\text {dark }}\right) \\
\left(\mathrm{nmol} \cdot \mathrm{s}^{-1}\right)\end{array}$ & $\begin{array}{c}\mathrm{R}_{0} \\
\left(\mu \mathrm{mol} \cdot \mathrm{s}^{-1}\right)\end{array}$ & $\begin{array}{c}\mathrm{R}_{25} \\
\left(\mu \mathrm{mol} \cdot \mathrm{s}^{-1}\right)\end{array}$ & $\begin{array}{c}\mathrm{R}_{0} / \mathrm{DW} \\
\left(\mathrm{nmol} \cdot \mathrm{g}^{-1} \cdot \mathrm{s}^{-1}\right)\end{array}$ & $\begin{array}{c}\mathrm{R}_{25} / \mathrm{DW} \\
\left(\mathrm{nmol} \cdot \mathrm{g}^{-1} \cdot \mathrm{s}^{-1}\right)\end{array}$ & $\begin{array}{c}\mathrm{DCG}_{25} \\
\left(\mathrm{mmol} \cdot \mathrm{d}^{-1}\right)\end{array}$ & $\begin{array}{c}\mathrm{RGR}_{25} \\
\left(\mathrm{mmol} \cdot \mathrm{g}^{-1} \cdot \mathrm{d}^{-1}\right)\end{array}$ \\
\hline Geranium & $1.15 \mathrm{c}$ & $15.3 \mathrm{a}^{\mathrm{z}}$ & $1.99 \mathrm{~b}$ & $7.28 \mathrm{a}$ & $0.62 \mathrm{~b}$ & $6.55 \mathrm{a}$ & $36.63 \mathrm{a}$ & $56.29 \mathrm{a}$ & $3.43 \mathrm{a}$ \\
\hline Marigold & $2.59 \mathrm{a}$ & $15.5 \mathrm{a}$ & $2.38 \mathrm{a}$ & $4.95 \mathrm{~b}$ & $0.65 \mathrm{~b}$ & $1.93 \mathrm{c}$ & $16.92 \mathrm{c}$ & $50.24 \mathrm{a}$ & $1.37 \mathrm{~d}$ \\
\hline Pansy & $1.37 \mathrm{c}$ & $13.4 \mathrm{a}$ & $2.14 \mathrm{~b}$ & $5.96 \mathrm{ab}$ & $0.60 \mathrm{~b}$ & $4.52 \mathrm{~b}$ & $29.93 \mathrm{~b}$ & $51.68 \mathrm{a}$ & $2.58 \mathrm{~b}$ \\
\hline Petunia & $2.06 \mathrm{~b}$ & $14.1 \mathrm{a}$ & $2.31 \mathrm{a}$ & $6.89 \mathrm{a}$ & $0.84 \mathrm{a}$ & $3.50 \mathrm{~b}$ & $28.10 \mathrm{~b}$ & $65.08 \mathrm{a}$ & $2.18 \mathrm{c}$ \\
\hline
\end{tabular}

${ }^{\mathrm{z}}$ Means within a column followed by the same letter are not significantly different according to Tukey's multiple comparison procedure $(P=0.05$, $\mathrm{n}=4)$. 
$<0.05)$, while there were no differences in $\mathrm{P}_{\text {gross }}$ among the other three species. The higher $\mathrm{P}_{\text {gross }}$ of petunia most likely was the result of the relatively large leaf area of these plants, as compared to that of the other species (data not shown). At low temperatures, $\mathrm{P}_{\text {gross }}$ may be limited by enzyme activity (Björkman et al., 1980), which explains the increase in $\mathrm{P}_{\text {gross }}$ with increasing temperatures from 8 to $22^{\circ} \mathrm{C}$. Photorespiration also increases with increasing temperature (Keys et al., 1977), and since photorespiration is not included in $\mathrm{R}_{\text {dark }}$ measurements, estimates of $\mathrm{P}_{\text {gross }}$ are not corrected for photorespiration. Increasing photorespiration with increasing temperature can explain the decrease in $\mathrm{P}_{\text {gross }}$ at temperatures above $22^{\circ} \mathrm{C}$. Stomatal effects may have contributed as well. The leaf-to-air vapor pressure deficit increased with increasing temperature, which may result in partial stomatal closure (Day, 2000).

Gross photosynthesis of all four species was less sensitive to temperature than either $\mathrm{P}_{\text {net }}$ or $\mathrm{R}_{\text {dark }}$, with $\mathrm{Q}_{10}$ values ranging from 0.9 to 1.2 , compared to 0.4 to 1.1 for $P_{\text {net }}$ and 2.0 to 2.4 for $R_{\text {dark }}$ (a $\mathrm{Q}_{10}$ value close to one indicates little response to temperature) (Table 1, Fig. 2). The low sensitivity of $\mathrm{P}_{\text {gross }}$ to temperature suggests that temperature effects on $\mathrm{P}_{\text {net }}$ were caused mainly by the increase in respiration with increasing temperature, rather than by temperature effects on the actual photosynthetic activity of the plants.

The $\mathrm{Q}_{10}$ for $\mathrm{P}_{\text {gross }}$ and $\mathrm{P}_{\text {net }}$ generally decreased with increasing temperature, although there was little change in the $\mathrm{Q}_{10}$ for $\mathrm{P}_{\text {gross }}$ of marigold, pansy, and petunia at temperatures above $22^{\circ} \mathrm{C}$. At low temperatures $\left(13\right.$ to $\left.15^{\circ} \mathrm{C}\right)$, the $\mathrm{Q}_{10}$ for $\mathrm{P}_{\text {gross }}$ of marigold was higher than that of pansy, indicating that $\mathrm{P}_{\text {gross }}$ of marigold increased more rapidly than that of pansy with increasing tem-
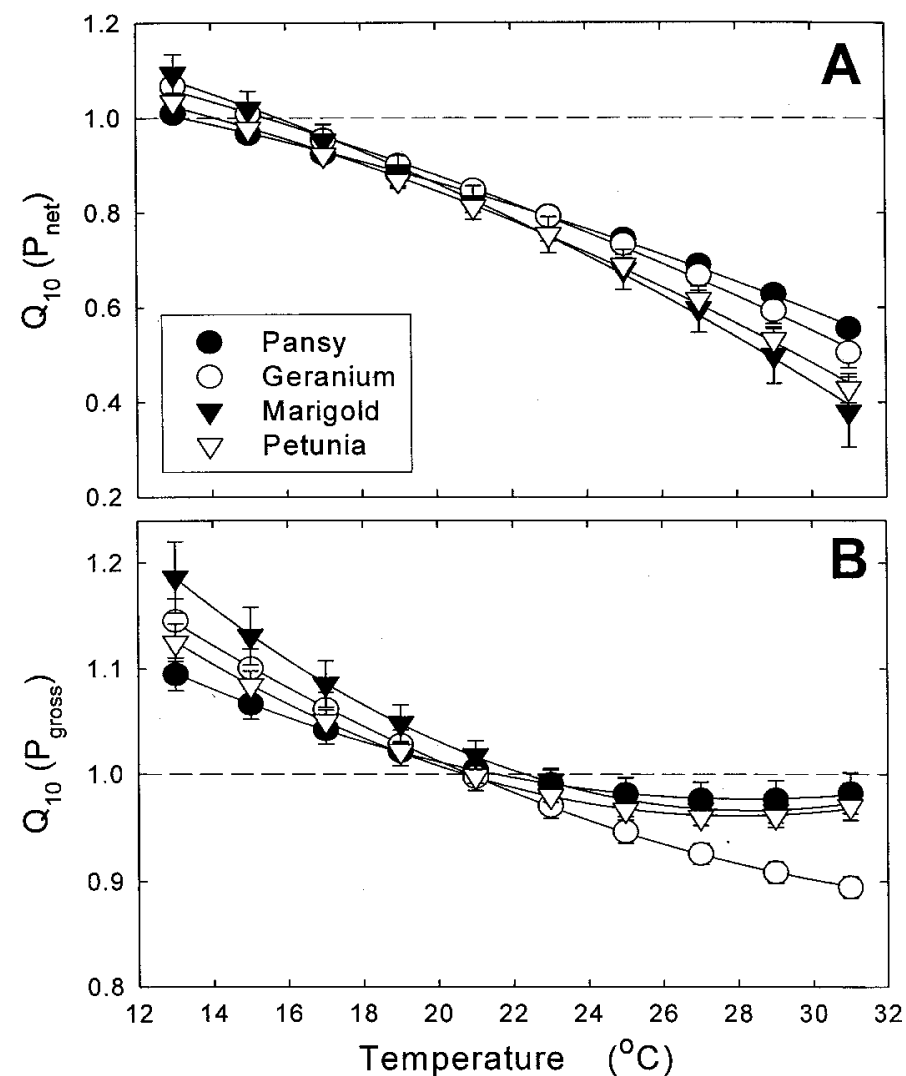

Fig. 2. The $\mathrm{Q}_{10}$ of $\left.\mathrm{A}\right)$ net photosynthesis $\left(\mathrm{P}_{\text {net }}\right)$ and $\left.\mathrm{B}\right)$ gross photosynthesis $\left(\mathrm{P}_{\text {gross }}\right)$ of four bedding plant species at different air temperatures. Data points are the mean \pm 1 standard error $(n=4)$. Error bars not shown are within the limit of the symbol. perature in this range. At temperatures $>26^{\circ} \mathrm{C}$, geranium had a lower $\mathrm{Q}_{10}$ for $\mathrm{P}_{\text {gross }}$ than the other species, indicating that its $\mathrm{P}_{\text {gross }}$ declined more rapidly at high temperatures.

At high temperatures, marigold and petunia had a lower $\mathrm{Q}_{10}$ for $\mathrm{P}_{\text {net }}$ than pansy $\left(>24{ }^{\circ} \mathrm{C}\right.$ for marigold and $>30{ }^{\circ} \mathrm{C}$ for petunia). Since there were no differences in $\mathrm{Q}_{10}$ for $\mathrm{P}_{\text {gross }}$ among marigold, pansy, and petunia at high temperatures, the higher $\mathrm{Q}_{10}$ for $\mathrm{P}_{\text {net }}$ of pansy apparently was the result of the high $\mathrm{Q}_{10}$ for $\mathrm{R}_{\mathrm{dark}}$ of petunia and marigold. Dark respiration of these two species increased more rapidly with increasing temperature, resulting in a more rapid decrease in $\mathrm{P}_{\text {net }}$ of petunia and marigold than that of pansy.

Although temperature effects on the $\mathrm{CO}_{2}$ exchange rate give a good indication how these physiological processes are affected by temperature, they are not a direct indicator of plant growth, since growth is affected by both photosynthesis and respiration. Among species, petunia had the highest DCG at temperatures $\leq 22$ ${ }^{\circ} \mathrm{C}$, while geranium and pansy had the highest DCG at $36{ }^{\circ} \mathrm{C}(P$ $<0.05$ ) (Fig. 3A). Daily carbon gain of all four species increased slightly from 8 to $\approx 12^{\circ} \mathrm{C}$ and decreased at higher temperatures. Daily carbon gain of marigold and petunia was negative (i.e., the plants would be expected lose carbon) at temperatures $>32{ }^{\circ} \mathrm{C}$, while DCG of geranium and pansy was negative at temperatures $>34{ }^{\circ} \mathrm{C}$. Many plant species have the ability to acclimate to
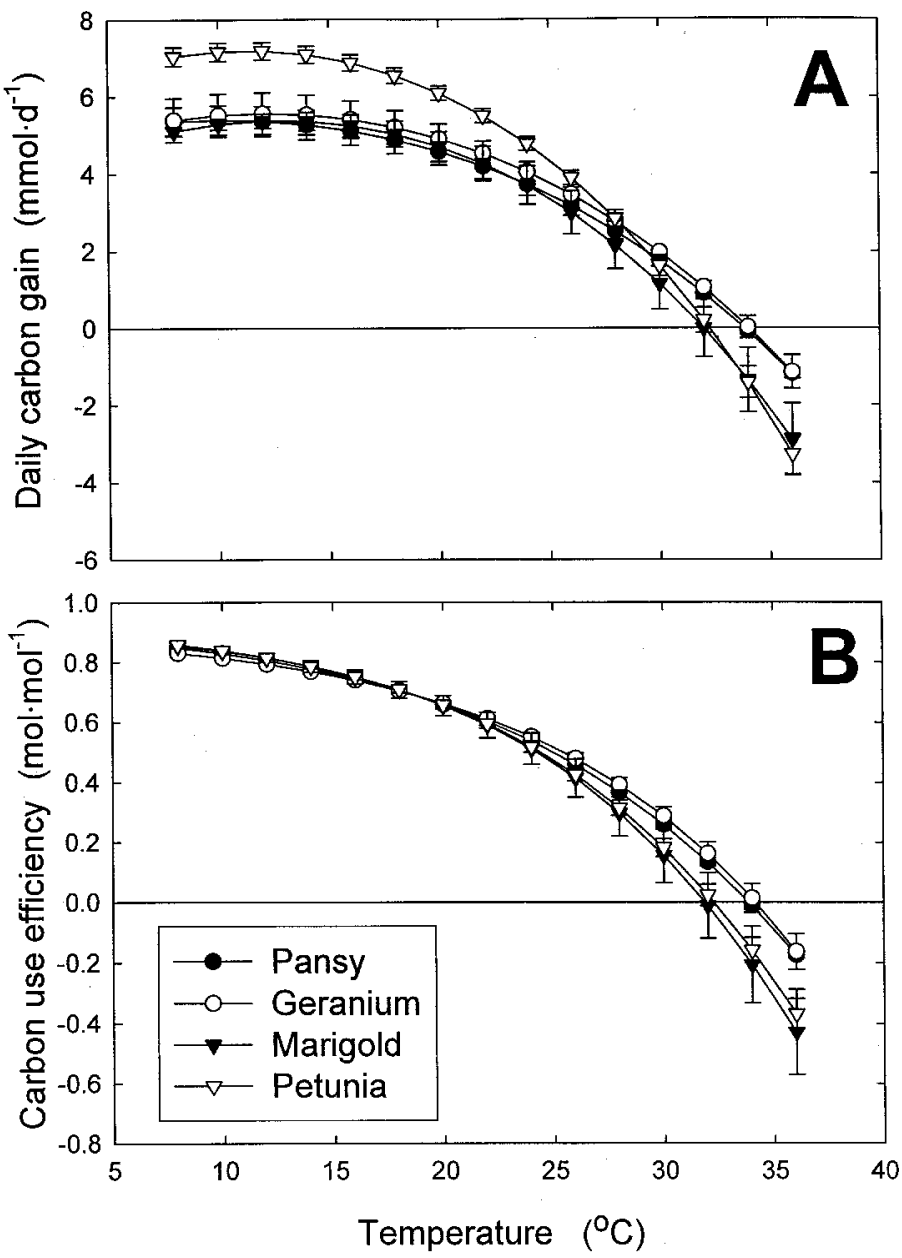

Fig. 3. The effect of short-term changes in air temperature on (A) the daily carbon gain (DCG), a measure of plant growth rate, and (B) carbon use efficiency (CUE), the ratio of carbon incorporated into the plant to the amount of carbon fixed in gross photosynthesis, of four bedding plant species. Data points are the mean (per plant) \pm 1 standard error $(n=4)$. Error bars not shown are within the limit of the symbol. 

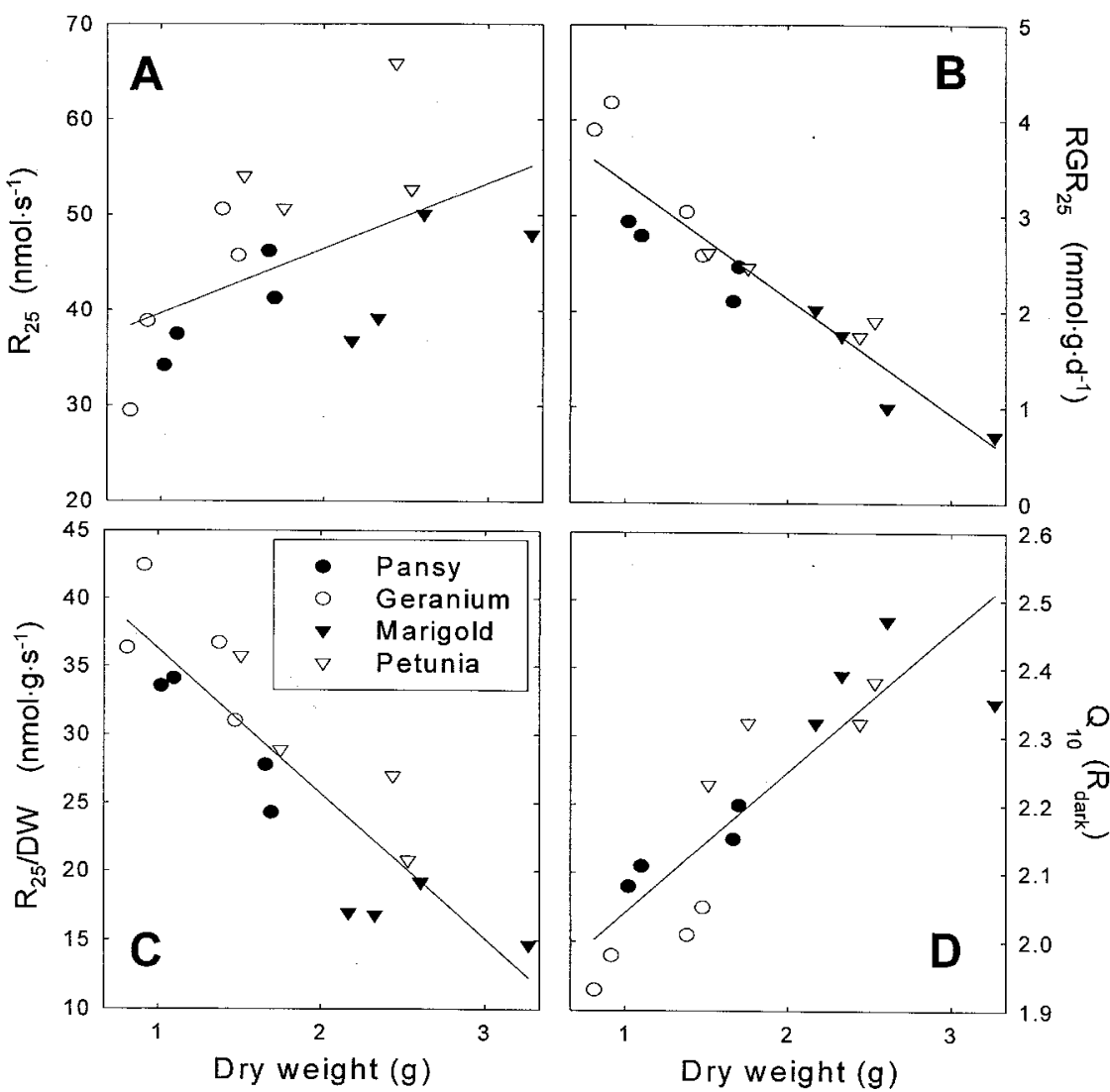

Fig. 4. The correlation between plant dry weight (DW) and A) estimated dark respiration at $\left.25^{\circ} \mathrm{C}\left(\mathrm{R}_{25}\right), \mathrm{B}\right)$ specific dark respiration at $\left.25{ }^{\circ} \mathrm{C}\left(\mathrm{R}_{25} / \mathrm{DW}\right), \mathrm{C}\right)$ relative growth rate at $25{ }^{\circ} \mathrm{C}\left(\mathrm{RGR}_{25}\right)$, and $\left.\mathrm{D}\right)$ the $\mathrm{Q}_{10}$ for dark respiration $\left[\mathrm{Q}_{10}\right.$ $\left(\mathrm{R}_{\mathrm{dark}}\right)$ ]. Data from the four different bedding plant species were combined for the regression analysis: $\mathrm{R}_{25}=33+6.8 \times \mathrm{DW}, r=0.53 ; \mathrm{R}_{25} / \mathrm{DW}=47-10.6 \times$ DW, $r=-0.89 ; \mathrm{RGR}_{25}=4.6-1.2 \times \mathrm{DW}, r=-0.93 ; \mathrm{Q}_{10}\left(\mathrm{R}_{\text {dark }}\right)=1.83+0.21 \times$ DW, $r=0.88$.

different environmental conditions, including temperature. Thus, it is important to realize that these DCG values predict short-term effects of temperature on growth, and do not imply that these species are unable to grow at temperatures $>34^{\circ} \mathrm{C}$. Species with the ability to acclimate to changing temperatures have higher optimal temperatures for photosynthesis when grown under warm conditions than under cool conditions (Björkman et al., 1980), while $\mathrm{R}_{\text {dark }}$ at a given temperature decreases (Hurry et al., 1996; Pearcy, 1977; Rook, 1969; Tranquillini et al., 1986). Therefore, if the plants in this study had been grown at higher temperatures, the temperature at which DCG became negative likely would have likewise been higher.

Growth of plants is a function of how many photosynthates are fixed in $\mathrm{P}_{\text {gross }}$ and the efficiency with which these photosynthates are converted into structural carbon (i.e., CUE). Carbon use efficiency did not differ among species at any temperature and decreased with increasing temperature (Fig. 3B), which is a typical response to short-term temperature changes (Bednarz and van Iersel, 2001; van Iersel and Lindstrom, 1999). Because of the ability of plants to acclimate to different temperatures, CUE of plants is much less sensitive to long-term changes in temperature than would be expected from these short-term measurements (J. Frantz, unpublished results; Gifford, 1995).

Differences in the temperature response of $\mathrm{R}_{\mathrm{dark}}$ among species were more pronounced than differences in $\mathrm{P}_{\text {net }}$ or $\mathrm{P}_{\text {gross }}$, but did not appear to be related to the heat tolerance of these species. Pansy, the most heat-sensitive of the four species, had intermediate values for $\mathrm{R}_{0}, \mathrm{R}_{0} / \mathrm{DW}$, and $\mathrm{Q}_{10}$ for $\mathrm{R}_{\text {dark. }}$. These results indicate that $\mathrm{R}_{\text {dark }}$-temperature response curves based on short-term temperature changes are not good indicators of the heat tolerance of a species. Species differences in photosynthetic (either $\mathrm{P}_{\text {net }}$ or $\mathrm{P}_{\text {gross }}$ ) responses to temperature also did not show a clear relationship to their heat tolerance.

Although differences in the $\mathrm{Q}_{10}$ for $\mathrm{R}_{\text {dark }}$ were significant among species (Table 1), these differences need to be interpreted with care. To test whether observed differences among species were true species effects, or indirect effects caused by differences in plant size among species, correlations between plant dry weight and $Q_{10}$ for $R_{\text {dark }}$ were determined. The $\mathrm{Q}_{10}$ was correlated with plant size ( $r=0.88, P<0.0001$; Fig. 4D), suggesting that species differences in $\mathrm{Q}_{10}$ may have been an indirect effect of differences in plant dry weight. To better understand species and dry weight effects on $\mathrm{R}_{\text {dark }}$, growth and respiration-related parameters were estimated for a temperature of $25^{\circ} \mathrm{C}$ (Table 1, Fig. 4). Although there were large difference in dry weight among species, estimated $\mathrm{DCG}_{25}$ did not differ, while there were significant differences in $\mathrm{RGR}_{25}, \mathrm{R}_{25}$, and $\mathrm{R}_{25} / \mathrm{DW}$ (Table 1). There was a positive correlation between $\mathrm{R}_{25}$ and plant dry weight, but this correlation was poor $(r=0.53$, $P=0.04$; Fig. 4A) and there was no correlation between dry weight and $\mathrm{DCG}_{25}(r=0.00$, results not shown). This indicates that large plants do not necessarily grow faster or respire more than small plants.

Dry weight was negatively correlated with both $\mathrm{R}_{25} / \mathrm{DW}(r=$ $-0.89, P<0.0001)$ and with $\mathrm{RGR}_{25}(r=-0.93, P<0.0001)$ (Fig. $4 \mathrm{~B}$ and $\mathrm{C}$ ), indicating that the metabolic activity of small plants was higher than that of large plants (per unit dry weight). These findings are similar to those of Bednarz and van Iersel (2001), who found a positive correlation between $R_{\text {dark }}$ of whole cotton

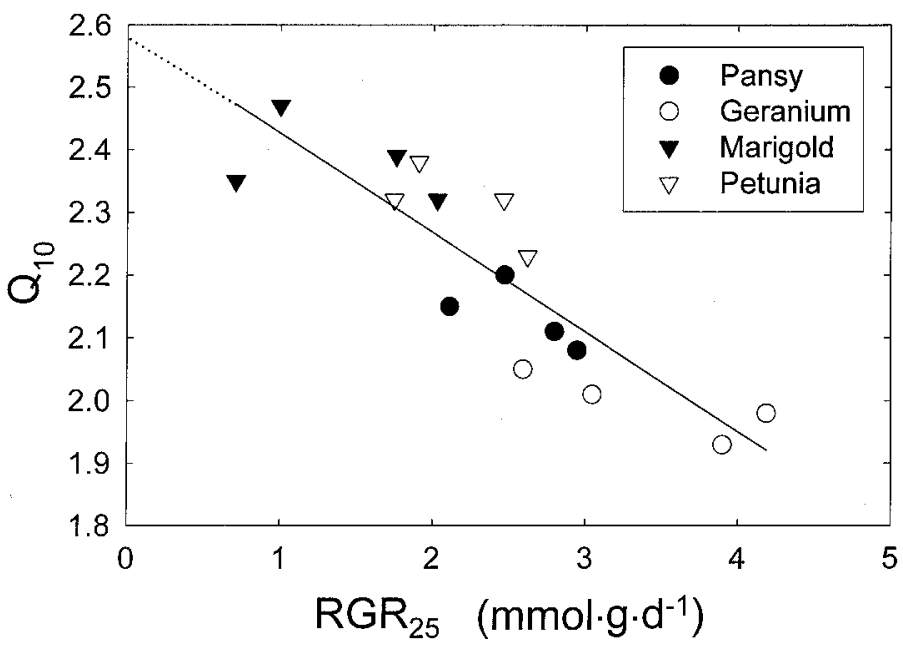

Fig. 5. The correlation between the $\mathrm{Q}_{10}$ for dark respiration and the estimated relative growth rate at $25^{\circ} \mathrm{C}$, assuming a 12-h photoperiod. Data from all four species were combined for the regression analysis $\left(\mathrm{Q}_{10}=2.58-0.16 \times \mathrm{RGR}_{25}\right.$, $r=-0.87)$. The $\mathrm{Q}_{10}$ for maintenance respiration can be estimated from the $\mathrm{Y}$ intercept of the regression line, because there is no growth respiration when the relative growth rate (and thus growth) is zero. 
(Gossypium hirsutum L.) plants and dry weight, but a stronger and negative correlation between $\mathrm{R}_{\text {dark }} / \mathrm{DW}$ and dry weight. The higher relative physiological activity of smaller plants (i.e. $\mathrm{RGR}_{25}$ and $R_{25} / D W$ ) may explain species differences in $Q_{10}$ for $R_{\text {dark }}$, as well as the correlation between the $Q_{10}$ for $R_{\text {dark }}$ and plant dry weight. These effects apparently were caused by different effects of temperature on maintenance and growth respiration. The maintenance respiration coefficient (maintenance respiration per unit dry weight) generally is considered to be temperaturesensitive, partly because of increased protein turnover at higher temperatures (de Wit et al., 1970; Thornley and Johnson, 1990).

In contrast, the growth respiration coefficient (growth respiration per unit growth) generally is considered to be temperatureinsensitive, unless temperature influences the chemical composition or metabolic pathways of the plants (Penning de Vries et al., 1974). Therefore, respiration of plants with a high ratio of maintenance to growth respiration would be expected to be more temperature sensitive than those with a low ratio, and thus to have a higher $\mathrm{Q}_{10}$ for $\mathrm{R}_{\text {dark }}$. The decrease in $\mathrm{RGR}_{25}$ and $\mathrm{R}_{25} / \mathrm{DW}$ with increasing plant size (Fig. 4B and C) suggests that larger plants allocated a larger fraction of their total respiration to maintenance. This is consistent with the finding that large plants had a higher $\mathrm{Q}_{10}$ than small plants (Fig. 4D).

Assuming that growth respiration is insensitive to temperature and that maintenance respiration of the different species increases similarly to increasing temperatures, the temperature sensitivity of maintenance respiration can be estimated from the regression of $\mathrm{Q}_{10}$ versus $\mathrm{RGR}_{25}$ (Fig. 5). When $\mathrm{RGR}_{25}=0$, there is no growth and therefore no growth respiration, so the $\mathrm{Y}$-intercept of the regression line (2.58) is an estimate of the $\mathrm{Q}_{10}$ for maintenance respiration. However, the calculated value for $\mathrm{RGR}_{25}$ (using [Eq. 4]) depends on the duration of the photoperiod used in the calculations of $\mathrm{DCG}_{25}$ [Eq. 2]. Thus, photoperiod duration also affects the $\mathrm{Y}$-intercept of the regression line of $\mathrm{Q}_{10}$ vs. $\mathrm{RGR}_{25}$, and this effect was quantified by using different photoperiod durations for the calculation of $\mathrm{RGR}_{25}$. Estimated values of the $\mathrm{Q}_{10}$ for the maintenance coefficient were $2.20 \pm 0.16(r=-0.43), 2.52 \pm$ 0.09 ( $r=-0.84), 2.58 \pm 0.08(r=-0.87), 2.61 \pm 0.08(r=-0.88)$, and $2.62 \pm 0.08(r=-0.88)$ for light periods of $6,9,12,15$, and 18 $h$, respectively (estimate \pm standard error, followed by the correlation coefficient of the regression line). Thus, the effects of photoperiod duration on the estimate of the $\mathrm{Q}_{10}$ for maintenance respiration were negligible, except when a light period of $6 \mathrm{~h}$ was used for the calculations. Using a 6-h photoperiod, however, not only resulted in a low estimate for $\mathrm{Q}_{10}$ with a relatively high standard error, but also in a low $r^{2}$ value for the regression line, indicating that this estimate was less accurate than those at longer photoperiods. Thus, an estimate of 2.5 to 2.6 for the $\mathrm{Q}_{10}$ for maintenance respiration of the four species in this study seems reasonable. $\mathrm{Q}_{10}$ estimates for the maintenance respiration of whole plants appear rare. Winzeler et al. (1976) estimated the maintenance respiration coefficient of whole uniculm barley (Hordeum vulgare L.) from $\mathrm{R}_{\mathrm{dark}}$ and dry weight measurements and found that it had a $Q_{10}$ of $\approx 3$. In contrast, Gifford (1995) reported that the maintenance respiration coefficient of wheat (Triticum aestivum L.) increased with an increase in temperature from 15 to $20{ }^{\circ} \mathrm{C}$, but was insensitive to a further increase in temperature, while the growth respiration coefficient decreased from 15 to $20{ }^{\circ} \mathrm{C}$ and increased with a further increase in temperature. This appears to be the only report of such a complex response of growth and maintenance respiration to temperature. Others have estimated the $\mathrm{Q}_{10}$ for maintenance respiration of specific organs, and reported a $\mathrm{Q}_{10}$ of $\approx 2$ (Marcelis and Baan Hofman-Eijer, 1995; Szaniawski and Kielkiewicz, 1982).

These results indicate that the response of $\mathrm{R}_{\text {dark }}$ to temperature depends on the ratio of maintenance to growth respiration in plants. Since growth and maintenance respiration depend on growth rate and plant size, respectively (Hesketh et al., 1980; $\mathrm{McCree}, 1974)$, these factors may affect respiration responses to temperature. Since RGR is the ratio between growth and weight, it may be especially important in interpreting respiratory responses to temperature. Unless differences in growth rate, plant size, and/or RGR are taken into account, it will be difficult to make meaningful comparisons of temperature effects on respiration among experimental treatments or species.

This problem may be especially important in whole plant measurements, because responses of all different organs are integrated in the measurements. Plants with a high RGR will have a higher proportion of young tissue than plants with a low RGR. Young, expanding leaves generally have higher respiration rates (per unit leaf area or dry weight) than older leaves (Yemm, 1965), presumably at least partly because most of the growth respiration occurs in young, growing tissues. Thus, the age distribution of the leaves will affect whole-plant $\mathrm{R}_{\text {dark }}$, as well as the ratio between growth and maintenance respiration. Since much of the response of $\mathrm{P}_{\text {net }}$ to temperature appears to be caused by changes in $\mathrm{R}_{\mathrm{dark}}$, rather than $\mathrm{P}_{\text {gross }}$, $\mathrm{RGR}$ is likely to affect the temperature response of $P_{\text {net }}$ as well as that of $R_{\text {dark }}$. This problem can be circumvented in leaf gas exchange measurements by measuring leaves of similar age. This may explain why leaf photosynthesis measurements have been used successfully to study differences in temperature responses among species (e.g., Al-Khatib and Paulsen, 1999; Higgins et al, 1992; Ranney and Ruter, 1997), while the current whole-plant measurements did not detect any species differences.

\section{Conclusions}

Although there were differences in carbon exchange rate among the four species used in this study, gas exchange-temperature response curves were not useful in determining the heat tolerance of different bedding plant species. Gross photosynthesis was not very sensitive to changes in temperature from 8 to 36 ${ }^{\circ} \mathrm{C}\left(\mathrm{Q}_{10}\right.$ between 0.9 and 1.2$)$, while the respiration rate of all four species increased exponentially $\left(\mathrm{Q}_{10}\right.$ of 2.0 to 2.4 , dependent on species). The rapid increase in $\mathrm{R}_{\text {dark }}$ with increasing temperature resulted in a decrease in $\mathrm{P}_{\text {net }}$ at high temperatures. All four species reached their maximal $\mathrm{P}_{\text {net }}$ at 14 to $15^{\circ} \mathrm{C}$. There were differences in the $R_{0}$ and $Q_{10}$ for $R_{\text {dark }}$ among the species. However, differences in $\mathrm{R}_{\text {dark }}$, and therefore indirectly $\mathrm{P}_{\text {net }}$, responses to temperature appeared to be caused by differences in plant dry weight and RGR, rather than true physiological differences among species. The $Q_{10}$ for $R_{\text {dark }}$ increased with increasing plant dry weight. This apparently occurred because large plants had a lower RGR and presumably a higher maintenance to growth respiration ratio than small plants. Since the maintenance respiration coefficient is temperature sensitive, while the growth respiration coefficient is not, plants with a high ratio of maintenance to growth respiration had a higher $\mathrm{Q}_{10}$ for $\mathrm{R}_{\text {dark }}$. The $\mathrm{Q}_{10}$ for the maintenance respiration was estimated from the correlation between $R G R$ and $Q_{10}$ for $R_{\text {dark }}$ and found to be $\approx 2.5$ to 2.6 . These results suggest that it is important to consider the ratio of maintenance to growth respiration when studying temperature effects on whole-plant respiration. 


\section{Literature Cited}

Al-Khatib, K. and G.M. Paulsen. 1999. High-temperature effects on photosynthetic processes in temperate and tropical cereals. Crop Sci. 39:119-125.

Armitage, A.M. 1994. Ornamental bedding plants. Wallingford, Oxon, U.K.

Bednarz, C.W. and M.W. van Iersel. 2001. Temperature response of whole-plant $\mathrm{CO}_{2}$ exchange rates of four upland cotton cultivars differing in leaf shape and leaf pubescence. Commun. Soil Sci. Plant Anal. 32:2485-2501.

Björkman, O., M.R. Badger, and P.A. Armond. 1980. Response and adaptation of photosynthesis to high temperatures, p. 233-249. In: N.C. Turner and P.J. Kramer (eds.). Adaptation of plants to water and high temperature stress. John Wiley and Sons, New York.

Bernacchi, C.J., E.L. Singsaas, C. Pimentel, A.R. Portis, and S.P. Long. 2001. Improved temperature response functions for models of Rubiscolimited photosynthesis. Plant Cell Environ. 24:253-259.

Day, M.E. 2000. Influence of temperature and leaf-to-air vapor pressure deficit on net photosynthesis and stomatal conductance in red spruce (Picea rubens). Tree Physiol. 20:57-63.

de Wit, C.T., R. Brouwer, and F.W.T. Penning de Vries. 1970. The simulation of photosynthetic systems, p. 47-70. In: I. Setlik (ed.). Prediction and measurement of photosynthetic productivity. PUDOC, Wageningen, The Netherlands.

Elmore, C.D. 1980. The paradox of no correlation between leaf photosynthetic rates and crop yields, p. 155-167. In: J.D. Hesketh and J.W. Jones (eds.). Predicting photosynthesis for ecosystem models. vol. 2. CRC Press, Boca Raton, Fla.

Evans, L.T. 1993. Crop evolution, adaptation and yield. Cambridge Univ. Press, Cambridge, U.K.

Gifford, R.M. 1995. Whole plant respiration and photosynthesis of wheat under increased $\mathrm{CO}_{2}$ concentration and temperature: Long-term vs. short-term distinctions for modelling. Global Change Biol. 1:385396.

Hesketh, J.D., R.S. Alberte, and J.W. Jones. 1980. Predicting dark respiration in the soil-plant system, p. 69-84. In: J.D. Hesketh and J.W. Jones (eds.). Predicting photosynthesis for ecosystem models. vol. 2. CRC Press, Boca Raton, Fla.

Higgins, S.S., F.E. Larsen, R.B. Bendel, G.K. Radamaker, J.H. Bassman, W.R. Bidlake, and A. Al Wir. 1992. Comparative gas exchange characteristics of potted, glasshouse-grown almond, apple, fig, grape, olive, peach, and Asian pear. Scientia Hort. 52:313-329.

Hurry, V., O. Keerberg, T. Pärnik, G. Öquist, and P. Gardeström. 1996. Effect of cold hardening on the components of respiratory decarboxylation in the light and in the dark in leaves of winter rye. Plant Physiol. 111:713-719.

Keys, A.J., E.V.S.B. Sampaio, M.J. Cornelius, and I.F. Bird. 1977. Effect of temperature on photosynthesis and photorespiration of wheat leaves. J. Expt. Bot. 28:525-533.

Larigauderie, A. and C. Körner. 1995. Acclimation of leaf dark respiration to temperature in alpine and lowland species. Ann. Bot. 76:245252.

Leonardos, E.D., M.J. Tsujita, and B. Grodzinski B. 1994. Net carbon exchange rates and predicted growth patterns in Alstroemeria
'Jacqueline' at varying irradiances, carbon dioxide concentrations, and air temperatures. J. Amer. Soc. Hort. Sci. 119:1265-1275.

Marcelis, L.F.M. and L.R. Baan Hofman Eijer. 1995. Growth and maintenance respiratory costs of cucumber fruit as affected by temperature, and ontogeny and size of the fruits. Physiol. Plant. 93:484492.

Martindale, W. and R.C. Leegood. 1997. Acclimation of photosynthesis to low temperature in Spinacia oleracea L. I. Effects of acclimation on $\mathrm{CO}_{2}$ assimilation and carbon partitioning. J. Expt. Bot. 48:1865-1872.

McCree, K.J. 1974. Equation for the rate of dark respiration of white clover and grain sorghum, as functions of dry weight, photosynthetic rate, and temperature. Crop Sci. 14:509-514.

Miller, A.M., M.W. van Iersel, and A.M. Armitage. 2001. Whole plant $\mathrm{CO}_{2}$ exchange responses of Angelonia angustifolia to temperature and irradiance. J. Amer. Soc. Hort. Sci. 125:606-610.

Pearcy, R.W. 1977. Acclimation of photosynthetic and respiratory carbon dioxide exchange to growth temperature in Atriplex lentiformis (Torr.). Plant Physiol. 59:795-799.

Penning de Vries, F.W.T., A.H.M. Brunsting, and H.H. van Laar. 1974. Products, requirements, and efficiency of biosynthesis: A quantitative approach. J. Theor. Biol. 45:339-377.

Ranney, T.G. and M.M. Peet. 1994. Heat tolerance of five taxa of birch (Betula): Physiological responses to supraoptimal leaf temperatures. J. Amer. Soc. Hort. Sci. 119:243-248.

Ranney, T.G. and J.M. Ruter. 1997. Foliar heat tolerance of three holly species (Ilex spp.): Responses of chlorophyll fluorescence and leaf gas exchange to supraoptimal leaf temperatures. J. Amer. Soc. Hort. Sci. 122:499-503.

Rook, D.A. 1969. The influence of growing temperature on photosynthesis and respiration of Pinus radiata seedlings. N.Z. J. Bot. 7:43-55.

Szaniawski, R.K. and M. Kielkiewicz. 1982. Maintenance and growth respiration in shoots and roots of sunflower plants grown at different root temperatures. Physiol. Plant. 54:500-504.

Thornley, J.H.M. and I.R. Johnson. 1990. Plant and crop modelling: A mathematical approach to plant and crop physiology. Clarendon Press, Oxford, U.K.

Tranquillini, W., W.M. Havranek, and P. Ecker. 1986. Effects of atmospheric humidity and acclimation temperature on the temperature response of photosynthesis in young Larix decidua Mill. Tree Physiol. $1: 37-45$.

van Iersel, M.W. and B. Bugbee. 2000. A semicontinuous, multichamber, crop $\mathrm{CO}_{2}$-exchange system: Design, calibration, and data interpretation. J. Amer. Soc. Hort. Sci. 125:86-92.

van Iersel, M.W. and O.M. Lindstrom. 1999. Temperature response of whole plant $\mathrm{CO}_{2}$ exchange rates of three magnolia (Magnolia grandiflora L.) cultivars. J. Amer. Soc. Hort. Sci. 124:277-282.

Winzeler, H., L.A. Hunt, and J.D. Mahon. 1976. Ontogenetic changes in respiration and photosynthesis in a uniculm barley. Crop Sci. 16:786790.

Yemm, E.W. 1965. The respiration of plants and their organs, p. 231310. In: F.C. Steward (ed.). Plant physiology. vol. 4A. Metabolism: Organic nutrition and nitrogen metabolism. Academic Press, New York.

Zelitch, I. 1982. The close relationship between net photosynthesis and crop yield. BioScience 32:796-802. 